\title{
SEMIOTIKA GUNA PENELITIAN OBJEK KEBUDAYAAN MATERIAL SENI
}

\author{
A.M.Susilo Pradoko \\ FBS Universitas Negeri Yogyakarta \\ Email: susilopradoko@yahoo.com
}

\begin{abstract}
Abstrak
Paparan kajian dalam tulisan ini akan mengungkapkan ciri-ciri kebudayaan material serta peranannya dalam masyarakat selanjutnya mengungkapkan cara penelitian dengan metode semiotika Roland Barthes berpaduan dengan analisis wacana. Metode kajian terlebih dahulu menjabarkan tentang kebudayaan material. Selanjutnya akan memaparkan bagaimana kebudayaan material tersebut diurai melalui analisa semiotik sehingga menjadi salah satu model pendekatan penelitian seni terhadap kebudayaan material. Hasil kajian sebagai berikut: Objek kebudayaan material seni adalah komponen material yang dapat dipersepsikan melalui sentuhan atau penglihatan hasil budi daya manusia untuk mencapai keindahan dan memenuhi kebutuhan hidup. Kebudayaan material dapat berupa: Artefak benda simbolik dalam aktifitas social, barang-barang (goods) kebutuhan, komoditi dan aktan. Objek kebudayaan material memiliki empat peranan penting dalam kehidupan manusia yaitu sebagai (1) penanda nilai, (2) penanda identitas, (3) serta wujud jaringan kekuasaan (4) sebagai wadah mitos. Penelitian objek kebudayaan material seni menggunakan semiotika Roland Barthes melakukan tahapan-tahapan utama yaitu yang pertama melihat struktur seluruh tanda-tanda yang tampak dalam kajian benda material tersebut secara denotasi. Langkah kedua adalah mengkaji pesan-pesan budaya material tersebut malalui pesan-pesan teks, dokumen, karya sastra, literatur sesuai peristiwa dan konteksnya. Langkah ketiga adalah pencarian makna sistem sekunder dengan menelusuri form dan concept-nya dan didapatkan sign baru, signification. Akhirnya menemukan makna sistem sekunder yang dapat berupa metabahasa, di mana perubahan yang terjadi adalah pada bagian ekspression dan makna sistem sekunder perubahan yang terjadi pada bagian isi atau content-nya.
\end{abstract}

Kata kunci: Kebudayaan material, semiotika, wacana. 


\title{
SEMIOTICS USED FOR CONDUCTING A RESEARCH ON THE OBECTS OF MATERIAL CULTURE
}

\begin{abstract}
Exposure studies in this paper reveal the characteristics of the material culture and its role in society, and further this study also reveals how a research is conducted by using Roland Barthes' semiotic method combined with the analysis of discourse. The methods of studies, first, describe the material culture and then explain how the material culture scrutinized through semiotic analysis then becoming one of the models of the art research approach on material culture. The results of this study show that the cultural object of art material is a material component that can be perceived through the senses of touch or sight and that is created by human to achieve beauty and the needs of live. Material culture can be in the form of the artifacts of symbolic objects in social activities, goods (goods) needs, commodities and aktan. Objects of material culture have four important roles in human life that is as (1) a marker value, (2) a marker of identity, (3) a form of the network of power, and (4) as the source of myths. The study on objects of material culture using the art of semiotic of Roland Barthes was conducted through four main stages. The first step was to see the entire structure of the signs that appear in the study of material objects denotatively. The second step was to assess the messages of the material culture through text messages, documents, literary works, and literature related to the occasion and context. The third step was the search for the meaning of the secondary system by tracing its form and concept and the result is a new sign, that is signification. Finally, the meaning of the secondary system was found, which can be metalanguage, where the change is in the expression and the changes in the secondary system occur on its content.
\end{abstract}

Keywords: material culture, semiotics, discourse. 


\section{A. PENDAhuluan}

Kebudayaan material adalah benda hasil olahan budaya manusia, benda ini memiliki peran tertentu bagi bagi kebutuhan manusia. Ian Woodward menjelaskan sebagai berikut:

" The term 'material culture' emphasizes how apparently inanimate things within the environment act on people, and are acted upon by people, for the perposes of carrying out social fungtions, regulating social relations and giving symbolic meaning to human activity " (Woodward, 2007: 3).

Kebudayaan material menekankan bagaimana benda tak berjiwa di antara lingkungan bertindak atas manusia dan diberlakukan manusia untuk tujuan fungsi sosial, mengatur relasi sosial, dan memberikan arti simbolis pada aktivitas manusia.

Terminologi Wodward di atas menjelaskan bahwa objek kebudayaan materi memberikan arti simbolis bagi manusia. Arti simbolis sangat berkaitan dengan ilmu tentang tanda, atau disebut sebagai semiotika. Objek kebudayaan material maka memiliki tanda-tanda yang akan mampu menggerakan manusia dan benda tersebut diaktifkan dan dihidupi oleh manusia, sebab tanda-tanda tersebut mngikat manusia.

Paparan dalam tulisan ini akan mengungkapkan terlebih dahulu penjabaran tentang kebudayaan material, meliputi ciri-ciri kebudayaan material dan cakupancakupannya dalam konteks hubungan bagi kebutuhan hidup manusia. Selanjutnya akan memaparkan bagaimana kebudayaan material tersebut diurai melalui analisa semiotik sehingga menjadi salah satu model pendekatan penelitian seni terhadap kebudayaan material.

\section{B. PEMBAHASAN}

Uraian untuk memecahkan permasalahan penelitian semiotika dalam objek kebudayaan material seni ini akan dibagi menjadi empat bagian, yaitu pertama menguraikan kebudayaan material seni dan yang kedua uraian tentang semiotika itu sendiri, dalam tulisan ini semiotika dibatasi pada pemunculan semiotika hingga pemikiran semiotika sistem mitos dari Roland Barthes, sedangkan semiotika trikotomi dari Charles Sander Peirce tidak dikupas dalam tulisan ini. Bagian ketiga 
memaparkan terapan dari semiotika Roland Barthes guna penelitian objek kebudayaan material seni. Bagian keempat merupakan bahan-bahan latihan kajian analisis semiotika mitos objek kebudayaan material seni hingga objek barang komoditi masa kini.

\section{Material Kebudayaan Seni}

Kebudayaan material sering dihubungkan dengan benda, objek, barangbarang, artefak, komoditas dan sekarang ini sering disebut pula sebagai aktan, yaitu suatu barang yang berfungsi menjiwai gerakan manusia. Benda memiliki eksistensi material dan konkrit tetapi benda tidak berjiwa membutuhkan aktor sehingga benda tersebut memiliki imajinasi jiwa dan aktifitas fisik. Objek adalah komponen budaya material yang dapat dipersepsikan melalui sentuhan atau penglihatan. Artefak biasanya dianggap sebagai benda simbolik dalam aktifitas sosial masyarakat. Barang-barang (goods) adalah objek yang diproduksi berdasarkan relasi kebutuhan pasar ditandai dengan nilai dalam sistem pertukaran, dalam konsep barang-barang produksi kapitalis. Komoditi adalah ekspresi teknis yang berhubungan dengan konsep barang-barang, masuk dalam kelompok barang-barang dagangan. Aktan adalah terminologi akhir-akhir ini peristilahan dari sosiologi ilmiah yang merujuk pada entitas baik manusia maupun benda yang memiliki kemampuan untuk bertindak secara sosial. (Woodward, 2007: 15).

Objek kebudayaan material memiliki empat peranan penting dalam kehidupan manusia yaitu sebagai (1) penanda nilai, (2) penanda identitas, (3) serta wujud jaringan kekuasaan (4) sebagai wadah mitos. Objek kebudayaan material diberi nilai-nilai yang disepakati dan berlaku bagi masyarakatnya. Objek kebudayaan material menjadi identitas suatu masyarakat tertentu. Objek kebudayaan material sebagi simbol hadirnya relasi kuasa melalui objek tersebut. Objek budaya material diberi pesan mitos melalui isi narasi atau cerita yang proses pembentukannya dipengaruhi oleh kekuasaan. Perwujudan cerita mitos tersebut digetok-tularkan (disebarluaskan) melalui sistem wacana/kuasa. Wacana-wacana yang dimunculkan membentuk paradigma pemikiran. Paradigma pemikiran inilah yang akhirnya 
mengubah perilaku masyarakat untuk menanggapi objek budaya material tersebut. Objek kebudayaan material dengan demikian merupakan penanda nilai, penanda identitas, wujud jaringan kekuasaan, serta wadah pesan mitos yang menjadi acuan perilaku bagi masyarakat pendukungnya (Pradoko, 2015: 205-206).

Seni menurut Herbert Read seperti yang dikutip Sony Kartika dalam bukunya Kritik Seni diungkap sebagai berikut.

"Seni merupakan usaha manusia untuk menciptakan bentuk-bentuk yang menyenangkan. Bentuk yang menyenangkan dalam arti bentuk yang dapat membingkai perasaan keindahan dan perasaan keindahan itu dapat terpuaskan apabila dapat menangkap harmoni atau satu kesatuan dari bentuk yang disajikan" (Read 1959:1, Dharsono, 2007:7).

Leo Tolstoy tulisannya tentang seni antara lain mengungkap sebagai berikut.

"Art is activity that produces beauty". pada bagian lain dinyatakan pula: “ The activity of art is based on the fact that a man receiving trough his sense of hearing or sight another man's expression of feeling, is capable of experiencing the emotion which moved the man who expressed it" (Tolstoy, 1979:36).

Objek kebudayaan material seni adalah barang-barang, benda-benda peninggalan budaya, objek benda yang mampu menjadi aktan sehingga mampu bertindak secara sosial, semua barang, benda, objek yang dibuat manusia tersebut dijiwai dengan budi daya manusia guna mewujudkan keindahan. Objek kebudayaan material seni dengan demikian bisa berwujud bangunan, arca, patung, relief, artefak, buku karya sastra, lukisan, perpaduan tulisan-gambar-ilustrasi, alat-alat/instrumen musik, alat-alat tari/kostum, teks/naskah/score musik, drama, tari, video musik, drama, tari, objek benda-benda karya seni kerajinan, termasuk objek barang-barang komoditi konsumen masa kini seperti: busana, perhiasan, hand phone, laptop, mobil yang diberi sentuhan keindahan dalam objek material tersebut.

\section{Semiotika Sistem Mitos Roland Barthes}

Ferdinand de Saussure melihat tanda terdiri dari signifiant (bahasa Perancis) dan signifie (bahasa Perancis). Dalam bahasa Inggris menjadi signifier dan signified. 
Barthes menggunakan teori significant-signifie yang dikembangkan menjadi teori tentang metabahasa dan konotasi. Istilah significant menjadi ekspresi (E) dan signifie menjadi isi (C). Namun, Barthes mengatakan bahwa antara $\mathrm{E}$ dan $\mathrm{C}$ harus ada relasi (R) tertentu sehingga terbentuk tanda (sign). Ini suatu konsep struktural seperti yang dikemukakan de Saussure. Konsep relasi ini membuat teori tentang tanda menjadi lebih mungkin berkembang karena $\mathrm{R}$ ditetapkan oleh pemakai tanda. Menurut Barthes E dapat berkembang membentuk tanda baru sehingga ada lebih dari satu penanda dengan $\mathrm{C}$ yang sama. Gejala ini disebut sebagai metabahasa atau kesinoniman (Hoed, 2014:57).

Proses adanya relasi dalam semiotika ini, menurut Roland Barthes mengakibatkan perkembangan makna, makna menjadi sangat kompleks. Ada makna denotatif, yaitu merupakan makna awal, makna pertama hubungan E dan C. Proses relasi manusia memunculkan dua kemungkinan makna tingkat sistem sekunder yaitu makna konotasi dan makna meta bahasa. Makna konotasi terjadi bila proses E-R-C pada sistem primer menjadi C pada sistem sekunder. Makna meta bahasa terjadi bila proses E-R-C pada sistem primer menjadi E pada sistem sekunder (Barthes, 1957, Sunardi, 2004:71-74, Hoed, 2014:178-179). Gambar skema konotasi dan denotasi sebagai berikut diambil dari penjelasan Benny H. Hoed dan St. Sunardi dengan ditambahkan sendiri kode tanda panah agar proses pada sistem sekundernya lebih jelas. Pada sistem sekunder konotasi yang berkembang adalah Content-nya atau isinya; sedangkan pada sistem sekunder metabahasa yang berkembang adalah Expressi-nya. Sistem konotasi memiliki formula (EC) R C sedangkan metabahasa dengan formula E R (EC) (Sunardi, 2004: 72).
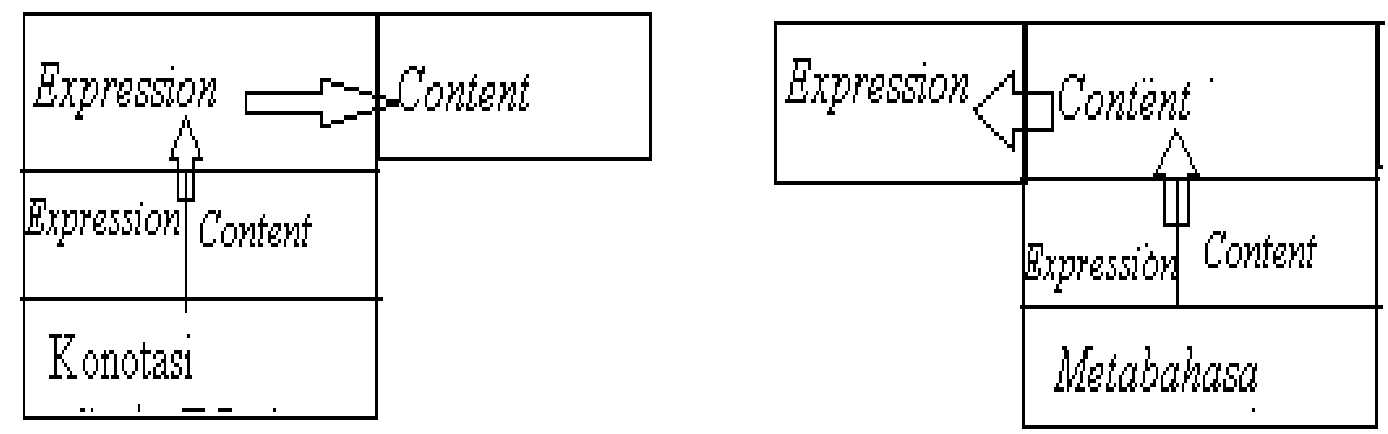


\section{Gambar 1. Bagan konotasi dan metabahasa sistem sekunder.}

Barthes mengembangkan pula semiotika sistem mitos untuk mengkaji fenomena kebudayaan. Ciri mitos dan fungsinya untuk memahami lingkungan alam dan diri manusia inilah yang dicoba diteorisasikan oleh Roland Barthes dengan menggunakan semiotik (Sunardi, 2004:89). Mitos sebagai kritik ideologis atas budaya massa dan sekaligus menganalisis secara semiotik cara kerja mekanik bahasa budaya massa dituliskan oleh Barthes dalam bukunya berjudul Mythologies (Sunardi, 2004:85).

Mitos yang dimaksudkan Roland Barthes bukanlah mitos seperti cerita yang panjang-panjang seperti dalam mitologi Yunani misalnya Pahlawan Hercules, Theseus atau Perang Troya, Mithos Barthes bukanlah cerita tentang dewa-dewi yang dianggap pernah ada dan diakui kebenarannya oleh masyarakat pendukungnya dan merupakan kisah cerita dengan narasi yang panjang. Mitos Roland Barthes merupakan a type of speech, suatu tipe wicara (jenis tindak tutur) yang disajikan dengan sebuah wacana (Barthes, 2013:152). Wacana-wacana yang dimunculkan membuahkan mitos, manakala mitos diterima maka perilaku masyarakat mengikuti wacana mitos tersebut, untuk itulah maka mitos Roland Barthes sering diungkapkan sebagai mitis sebab bentuk mitosnya berbeda namun sifat-sifat mitosnya merasuki melalui apa yang diwacanakan. Mitos tak menyembunyikan dan tak memamerkan apapun: ia hanya mendistorsi; ia hanyalah sebuah pembelokan (Barthes, 2013:186). Perubahan-perubahan yang terjadi pada sistem pemaknaan sekunder akan mengungkap pembelokan-pembelokan tersebut akibat sistem mitis yang bekerja dalam masyarakat pendukungnya.

Mitos merupakan suatu proses suatu sistem penandaan, sebagai sistem semiotik mitos dapat diuraikan sebagai tiga unsur yaitu signifier, signified dan sign pada sistem tingkat pertama atau sistem primer. Pada sistem sekunder Barthes menggunakan istilah berbeda untuk ketiga unsur itu, yaitu form, concept, dan signification (Sunardi, 2004:85). Barthes membuat skema sistem mitos seperti digambarkan dalam bagan 24 berikut ini. 


\begin{tabular}{|c|l|l|}
\cline { 2 - 3 } (Sistem Primer) & 1.Signifier & 2.Signified \\
\cline { 2 - 3 } & \multicolumn{2}{|c|}{ 3.Sign (Meaning) } \\
\cline { 2 - 3 } (Sisitem Sekunder) & $\begin{array}{l}\text { I.Signifier } \\
\text { Form }\end{array}$ & $\begin{array}{c}\text { I.Signified } \\
\text { Concept }\end{array}$ \\
\cline { 2 - 3 } & \multicolumn{2}{|c}{ IIIgn) Signification } \\
\hline
\end{tabular}

Gambar 2. Skema sistem Mitos (Sumber: Sunardi, 2004:315).

Sistem primer yang mencakup signifier, signified, dan sign diambil sepenuhnya menjadi bentuk baru pada sistem sekunder menjadi form, concept dan signification. Kalau sistem pertama (primer) adalah sistem linguistik, sistem kedua adalah sistem mitis yang mempunyai keunikannya. Sistem kedua (sekunder) memang mengambil model sistem pertama, akan tetapi tidak semua prinsip yang berlaku pada sistem primer berlaku pada sistem sekunder (Sunardi, 2004:89).

Adanya sistem mitos, yang merupakan ungkapan-ungkapan, cerita singkat panjang, narasi-narasi kesemuanya sebenarnya merupakan pesan-pesan yang disampaikan melalui sistem wacana. Wacana merupakan produk pengetahuan, sebagai suatu bentuk pengetahuan yang mengatur dan meregulasi cara praktik sosialkemasyarakatan dibicarakan, pengetahuan tidaklah bebas murni sebagai pengetahuan namun ada pengaruh kekuasaan (Rabinow, 2002:9). Wacana yang dipahami Foucault sebagai penjelasan, pendefinisian, pengklasifikasian, dan pemikiran tentang orang, pengetahuan, dan sistem abstrak pemikiran manusia, menurut Foucault tidak lepas dari relasi kuasa. Wacana selalu bersumber dari pihak yang memiliki kekuasaan dan dari mereka yang memiliki pemikiran kreatif. Hal ini memungkinkan mereka untuk membangkitkan relasi kekuasaan dan pengetahuan dalam suatu sistem sosial, dan kemudian dengan berpijak pada tautan relasi tersebut mereka mampu memproduksi wacana yang kebenarannya bisa diakui dan bertahan pada suatu rentang historis tertentu (Kali, 2013:3). Relasi antara produk pengetahuan yang mengatur dan meregulasi masyarakat dengan kekuasaan tidak dengan mudah tampak namun perlu kajian analisis peristiwa serta pernyataan-pernyataan yang muncul, dilanjutkan 
dengan menganalisis secara kritis sebab-akibat mengapa pernyataan semacam itu dimunculkan.

Roland Barthes mengungkapkan adanya sistem pemaknaan primer dan sekunder dengan memberi contoh caver gambar pada majalah Paris Match. Pada sistem primer makna secara denotasi adalah seorang serdadu algir sedang memberi hormat pada bendera Negara Perancis, Tricolour. Makna pada sistem sekunder fenomena gambar tersebut adalah bahwa Negara Perancis yang besar, demokratis, penyayang, penuh persaudaraan ternyata menjajah Bangsa Algeria (Barker, 2008 ).

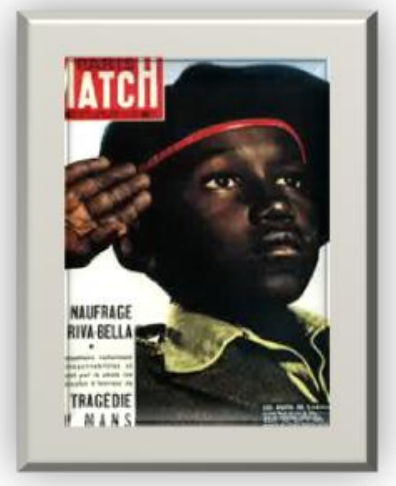

\section{Gambar 3. Penghormatan pada Tricolour}

Objek kebudayaan material terlebih bidang seni selalu memiliki makna denotasi dan konotasi, sebab seni leterleg, wadhag bukanlah seni yang sifatnya tinggi namun dianggap sebagai seni yang dasar.

\section{Terapan Semiotika guna Penelitian Objek Material Seni.}

Salah satu wujud kebudayaan material misalnya Gamelan Sekaten. Fenomena Gamelan Sekaten menjadi fokus penelitian kebudayaan material dengan menggunakan pisau analisis semiotika sitim mitos dari Roland Barthes. Agar lebih

mudah proses mengurai dan memperoleh versteken mengunakan sistem semiotika Barthes maka dibuat bagan analisis semiotika mitos gamelan sekaten sebagai berikut: 


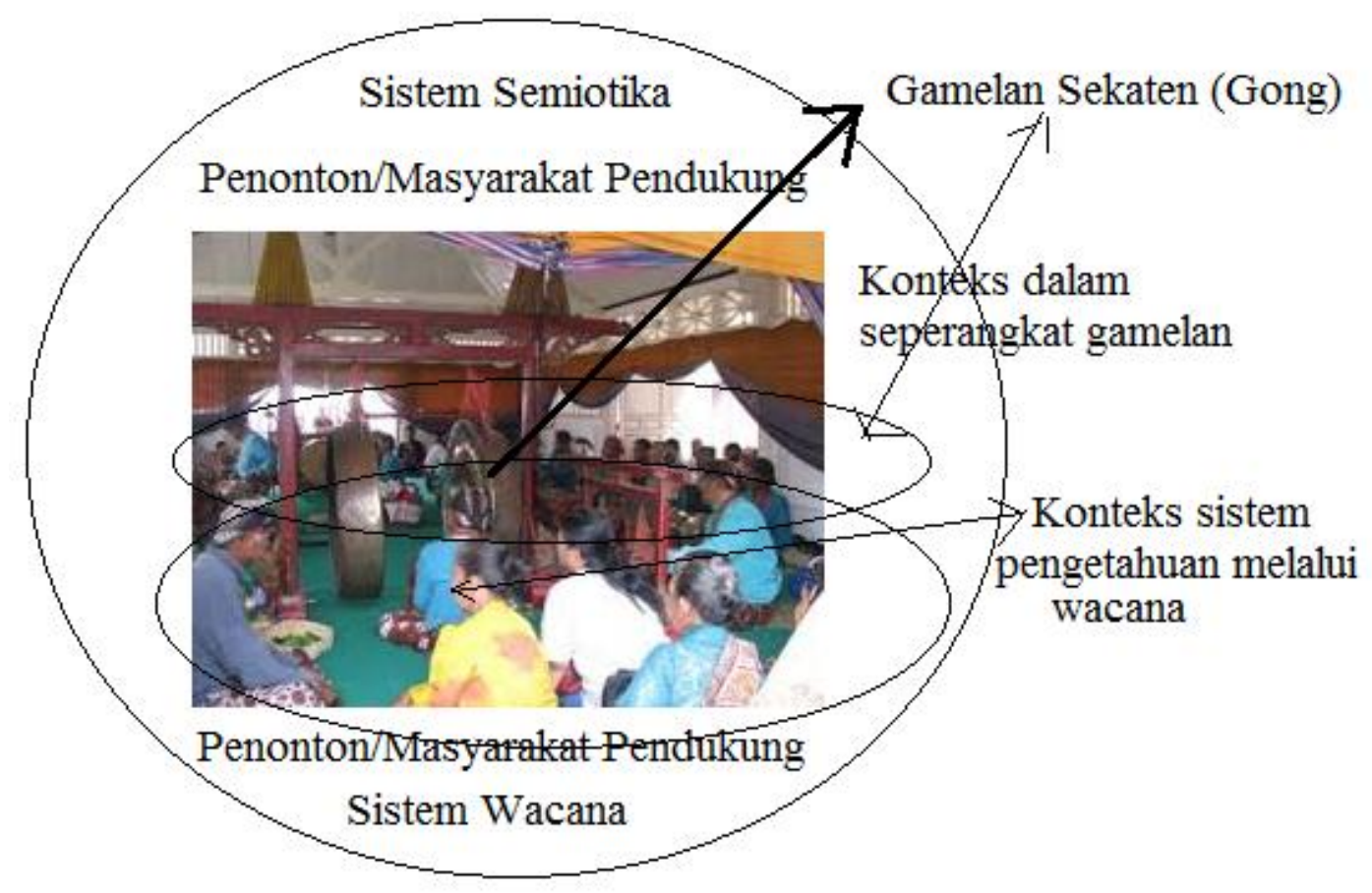

Gambar 4. Bagan analisis semiotika mitos gamelan sekaten

Gong merupakan alat musik paling besar yang terbuat dari logam di antara seperangkat peralatan musik gamelan sekaten, dalam sistem permainan gamelan adalah sebagai penentu irama, pemberi aksen kuat dan memberikan acuan pola bentuk gendhing. Inilah yang merupakan makna secara denotasi, selanjutnya gong tersebut dalam masyarakat pendukungnya terdapat sistem mitos di mana Gong merupakan gagasan representasi kebesaran, keagungan, representasi pengganti raja. Gong mendapat nama Kyai, yaitu Kyai Nogowilogo dan Kyai Guntur Madu. Gong yang dipersonkan menjadi representasi kehadiran raja, sementara raja sendiri merupakan wakil Allah di dunia ini maka permohonan atas Gong Kyai Nogowilogo dan Kyai Guntur Madu juga akan mendapat kesejahteraan, keselamatan, anugerah sesuai dengan permintaanya, kemenangan (pada waktu Kapten Taks terbunuh maka dibunykan pula saat itu gamelan sekaten). Selengkapnya penjelasan ini diringkas dalam bagan semiotika sistem mitos Gaong Gamelan Sekaten berikut ini. 


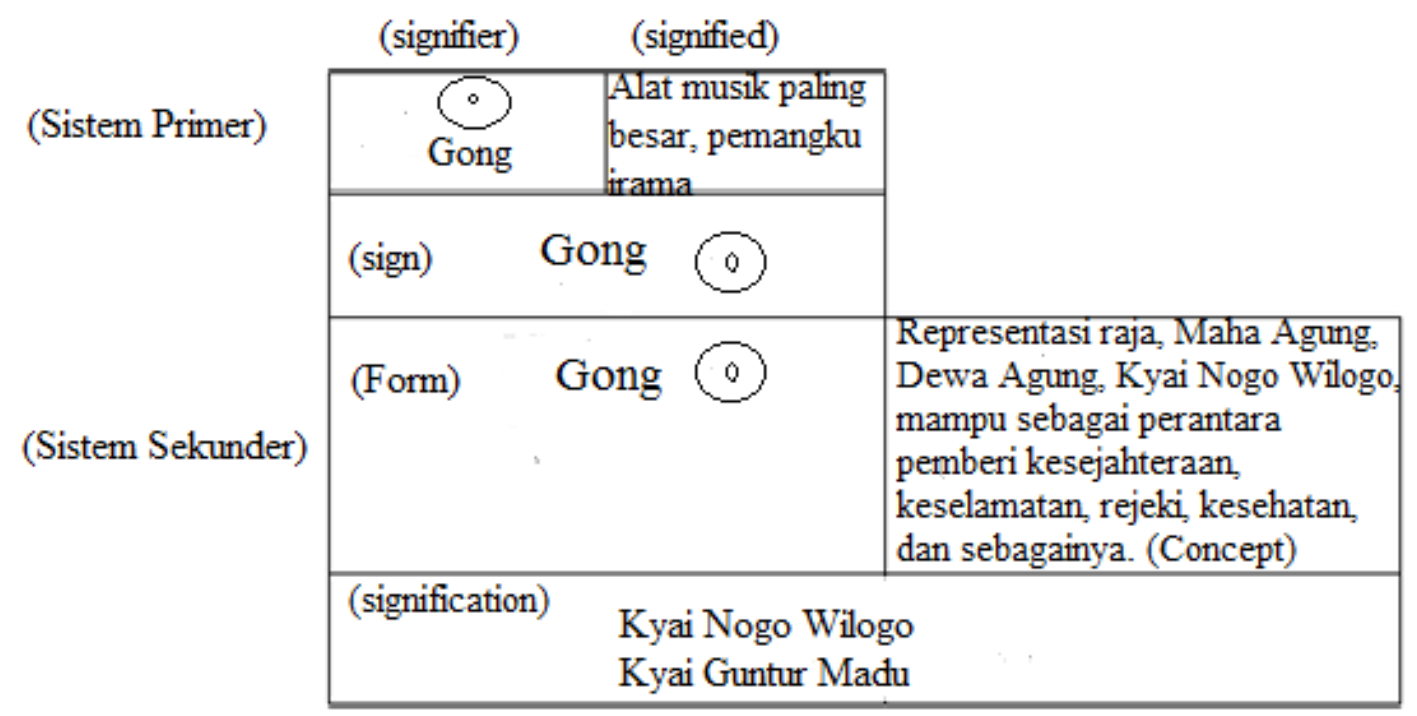

Gambar 5. Bagan semiotika sistem mitos Gong Gamelan Sekaten

Pada sistem primer makna denotasi, gong (signifier) adalah (signified) alat musik terbuat dari logam yang berwujud paling besar dan berfungsi sebagai penentu irama, penentu bentuk lagu dan penegasan bentuk gendhing . Pada sistem sekunder, sistem primer (gong) diambil alih sepenuhnya sehingga seutuhnya wujudnya tetap gong, pada sistem sekunder ini Barthes member nama Form bukan Sign untuk membedakan dengan yang pertama. Gong (Form) berarti representasi kehadiran Maha Agung, Dewa Agung, Raja, Kyai Agung yang mampu memberi perantara mendapatkan keselamatan, kesejahteraan, rejeki, kesehatan (concept). Form dan Concept-nya menyatu melalui sistem mitos yang diterima oleh masyarakat pendukungnya sehingga menjadi Kyai Nogo Wilogo maupun Kyai Guntur Madu yang terletak di kedua Pagongan sebelah utara dan selatan.

Objek kebudayaan material seni tidak hanya gamelan, namun barang dan benda apa saja seperti yang telah dipaparkan terdahulu, untuk lebih jelasnya berikut ini dipaparkan analisis semiotika mitos arca durga, namun karena terbatasnya tempat uraian ini maka hanya dimunculkan bagan sistem semiotika sistem mitos sistem sekunder metabahasa serta keterangan secara garis besar saja, selanjutnya diinterpretasi dan dinarasikan secara imajinatif pembaca. 


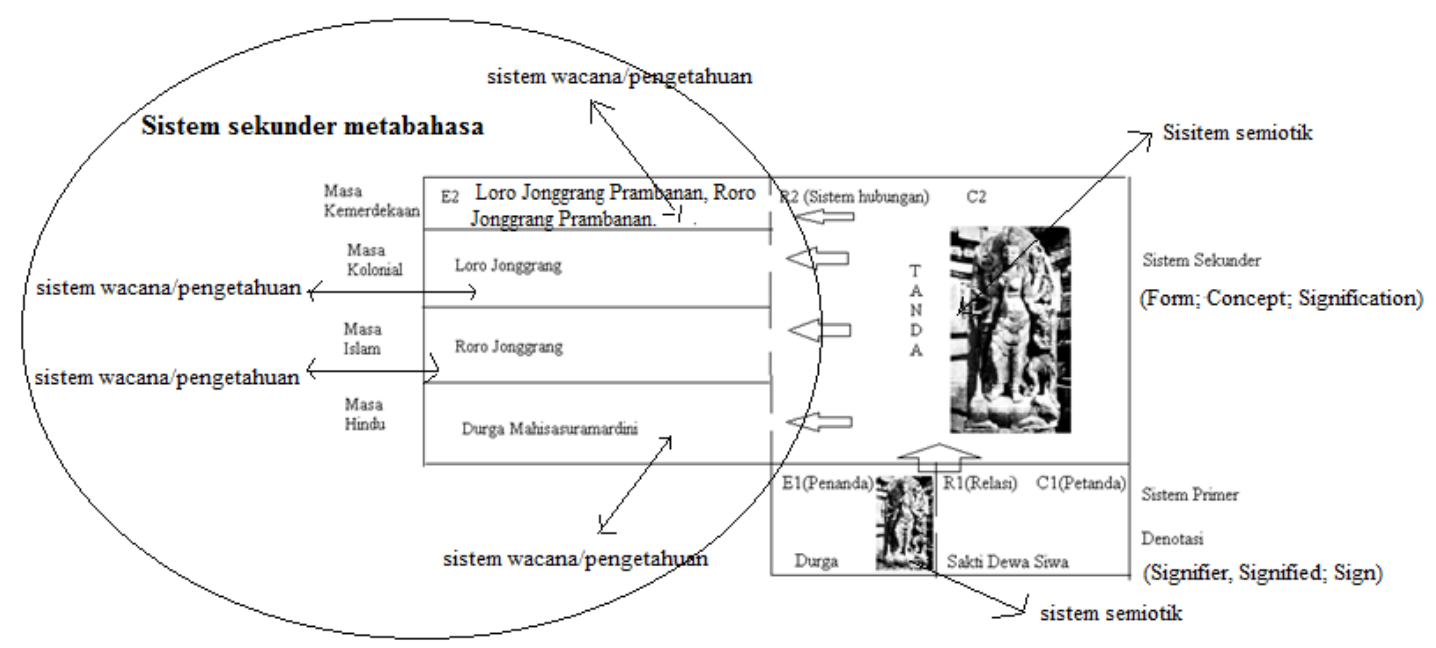

Gambar 6. Bagan semiotika sistem mitos meta bahasa Arca Durga

Keterangan: Pada bagan tersebut ditampilkan sistem primer Arca Durga, selanjutnya bagian sistem sekunder terjadi perubahan makna matabahasa dimulai sejak jaman masa pengaruh Hindu, masa pengaruh Islam, masa Kolonial dan masa Kemerdekaan. Metabahasa terjadi karena berlakunya sistem mitos melalui proses sistem pengetahuan/wacana, seperti halnya uraian terdahulu kebudayaan material Gong Sekaten menjadi mitos Maha Agung guna memohon berkah, kesejahteraan dst. (content konotasi), Kyai Nogo Wilogo sebagai perubahan metabahasa. Ada dua sisi penting pisau analisis dalam bagan tersebut yaitu analisis semiotika sistem mitos dan analisa wacana yang memunculkan sistem mitos tersebut.

\section{Bahan Analisis Semiotika Sistem Mitos Objek Kebudayaan Material}

Pada bagian latihan ini ada objek kebudayaan material yang dilengkapi dengan narasi sumber tulisannya namun juga ada yang tidak ada. Bahan yang dilengkapi degan narasi akan lebih mudah untuk mencari makna denotasi serta konotasinya, melalui sistem sekunder dan sistem primer dengan analisis wacana yang memunculkan mitos sehinga bersesuaian dengan sistem semiotik, tanda-tanda yang diekspresikannya. 


\section{Relief Upacara Korban Raja Dasarata, Cuplikan Relief Ramayana Prambanan.}

\section{Relief:}

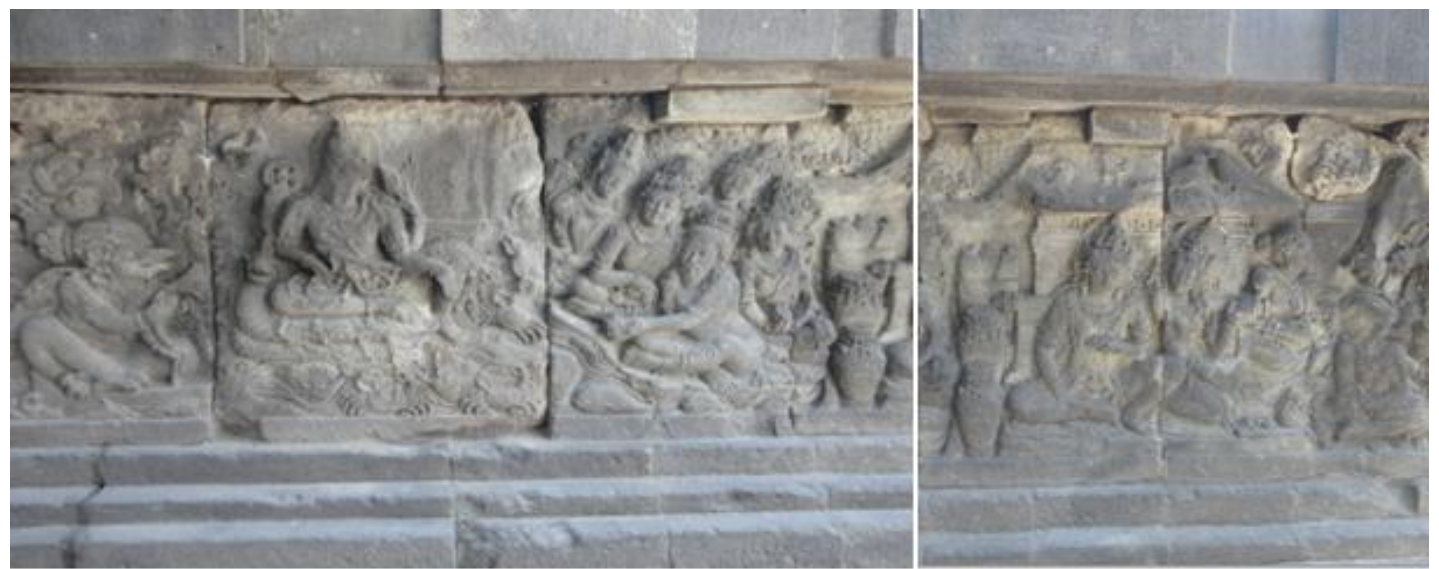

Gambar 7. Adegan upacara ritual, adegan Dewa Wisnu, adegan permohonan para dewa kepada Dewa Wisnu, adegan Istana Dasarata (Foto Pradoko, 2014).

\section{Narasi:}

Pada saat raja Dasarata yang berbudi luhur mengadakan ritual dan upacara korban sebagai dharma, di kayangan para Dewa mengadakan pertemuan ihwal permohonan para dewa agar Dewa Wisnu berkenan turun ke dunia dan membunuh Rahwana yang selalu sewenang-wenang, angkara murka, membuat kesengsaraan serta bertindak semena-mena terhadap perempuan (Poerbatjaraka, 1952:29, Rajagopalachari, 1958:26).

Pada saat Dasarata mempersembahkan korban ritual upacara dharmanya, para dewa berkenan dan memberikan semangkuk payas. Dewa berpesan agar memberikan payas kepada para istrinya. Dengan hati girang tak terperi, Dasarata menerima mangkuk itu dan membagikannya kepada ketiga istrinya, yakni Dewi Kausalya, Sumitra dan Kaikeyi. Ia berikan sebagian kepada Dewi Kausalya, sebagian yang lain kepada Sumitra. Separuh sisa bagian Sumitra diberikan kepada Kaikeyi dan sisanya dihabiskan Sumitra. Dewi Kausalya kemudian mengandung dan melahirkan titisan Dewa Wisnu, yaitu Rama yang selanjutnya memiliki misi untuk membunuh Rahwana. Kaikeyi melahirkan Bharata dan Sumitra melahirkan Lesmana 
dan Satruguna, karena meminum minuman Dewata dua kali (Poerbatjaraka, 1952:5051, Rajagopalachari, 1958:27).

\section{Aspek Analisis:}

Sistem primer; sistem sekunder;signifier; signified; sign; form, concept, signification; analisis mitos melalui sistem wacana/pengetahuan yang muncul; materi relief, ide gagasan yang muncul; nilai-nilai yang ada; nilai religius; nilai social; nilai-nilai acuan perilaku; nilai-nilai budi pekerti; aspek nilai kebaikan; aspek nilai-nilai kejahatan; makna denotasi; makna konotasi. Dua bagian analisis utama yaitu aspek semiotik berkaitan dengan tanda dan aspek semantik yang berkaitan dengan pemaknaan melalui narasi dan wacana yang muncul.

\section{Terapan Analisis Semiotika Mobil: Mercy}

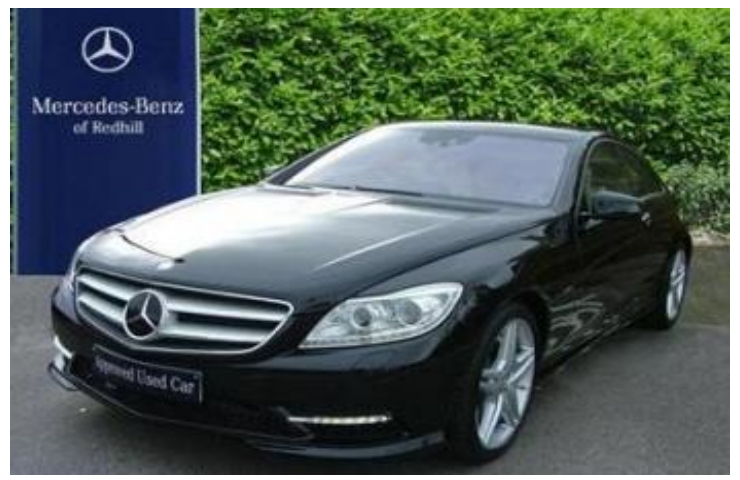

Gambar 8. Mobil Mercy

Narasi:

Waktu dan konteks narasi saat muncul.. ?

Analisis Semiotika Mitos: Sitem primer; sistem sekunder; konotasi; metabahasa denotasi; sistem pengetahuan/wacana dalam masyarakat yang muncul, dasar pemikiran semiotika sistem mitos. 


\section{Semiotika Suzuki Karimun Wagon}

\section{Wujud Mobil:}

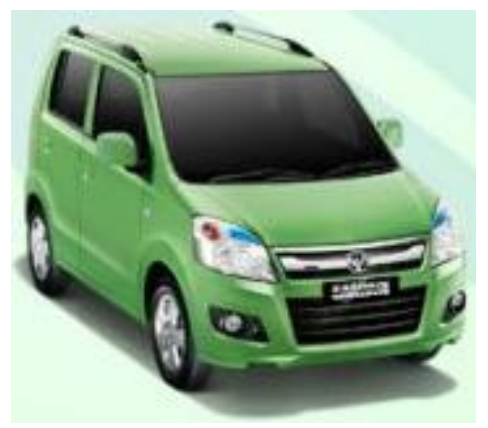

\section{Narasi:}

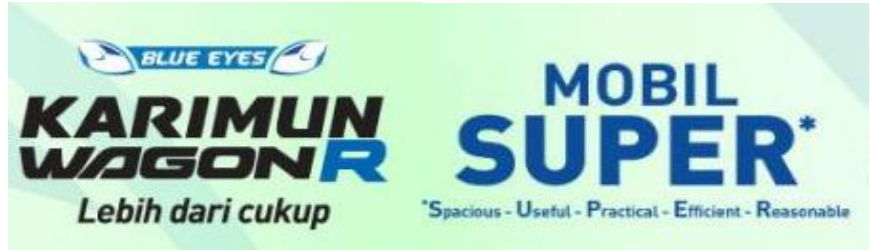

Gambar 9. Mobil Karimun Wagon R

KARIMUN WAGON R, produk Kendaraan Bermotor Roda Empat Hemat Energi \& Harga Terjangkau (KBH2), or Low Cost Green Car (LCGC) yang diperkenalkan oleh PT. Suzuki Indomobil Sales (SIS) menjadi jawaban bagi masyarakat modern Indonesia dengan memiliki unsur SUPER (Spacious, Useful, Practical, Efficient, Reasonable). Dengan perpaduan harapan dan kebutuhan akan kendaraan yang dapat menyelaraskan antara kebutuhan transportasi yang multiguna, gaya hidup dengan kepedulian lingkungan hidup itulah yang dikembangkan dengan oleh Suzuki yang mengerti akan kebutuhan masyarakat Indonesia yang selaras dengan brand promise dari Karimun Wagon R, yaitu ”Lebih dari cukup”. (sumber: Suzukikaltim.com; Suzuki.co.id, diunduh tgl 29 juli 2015)

Analisis Sistem Semiotika Mitos: Sistem primer; sistem sekunder; sign; signifier; signified; form; concept: sistem mitos, pengetahuan yang muncul; signification. 


\section{Analisis Semiotika Tari:}

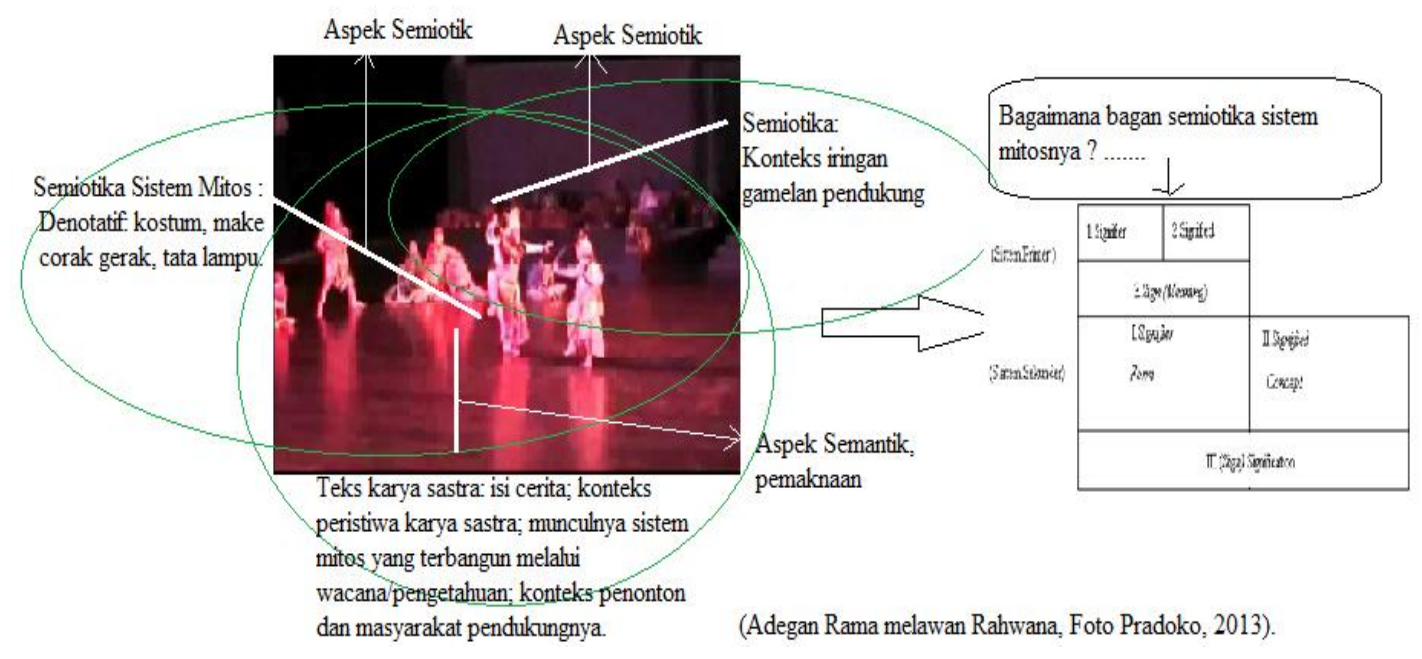

Gambar 10. Adegan Rama melawan Rahwana

Analisis Semiotika Produk Kosmetic:
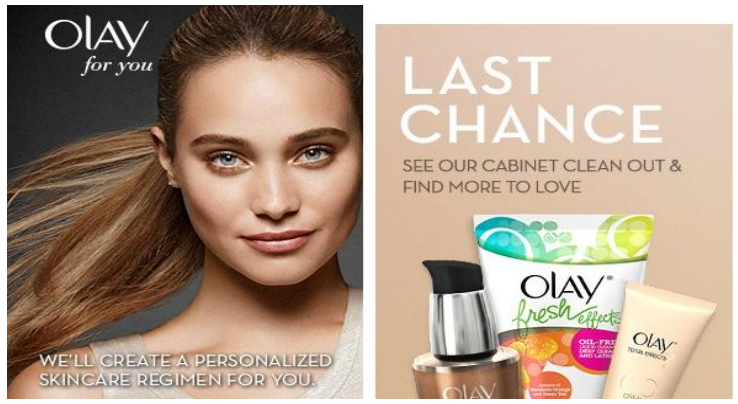

Gambar 11. Produk kosmetik OLAY

Semiotika sistem mitos-nya R. Barthes ?

\section{Analisis Semiotika Produk Makanan}

\section{KitKat:}



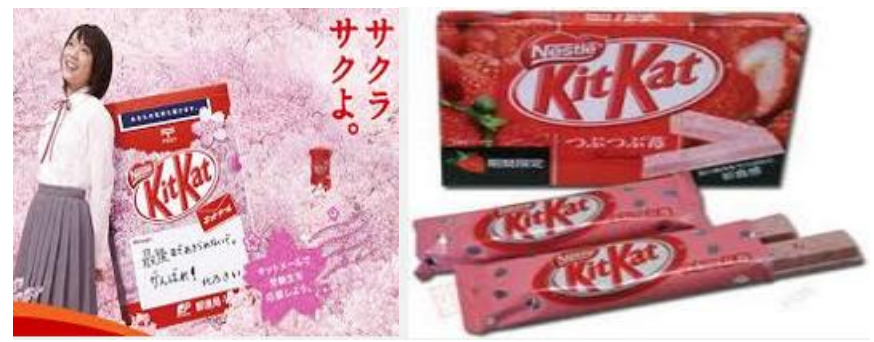

Gambar 12. Produk makanan Kit-Kat

Produk makanan ini pada tahun 2005 sangat laris di Jepang. KitKat, ungkapan dalam bahasa Jepang Kitto Katsu yang berarti semoga beruntung. Marianne Rosner Klimchuk dan Sandra A.Krasovec menuliskan sebagai berikut.

"Suatu laporan pada bulan Agustus 2005 edisi berita dunia BBC menyatakan terjadi lonjakan penjualan cokelat batang Kit Kat produksi Nestle di Jepang karena nama cokelat batang itu mirip dengan ungkapan dalam bahasa Jepang Kitto Katsu yang berarti semoga beruntung. Orang tua dan siswa sekolah suka membeli KitKat sebagai 'jimat keberuntungan' pada saat ujian " (Kimchuk dan Sandra A.K., 2006:48).

Bagaimanakah denotasi gambar ilustrasinya? Bagaimanakah analisis semiotika mitos Roland Barthes pada kasus desain kemasan ini? Apa pengaruhnya dalam masyarakat?

\section{KESIMPULAN}

Objek kebudayaan material seni adalah komponen material yang dapat dipersepsikan melalui sentuhan atau penglihatan hasil budi daya manusia untuk mencapai keindahan dan memenuhi kebutuhan hidup. Artefak biasanya dianggap sebagai benda simbolik dalam aktifitas social masyarakat. Barang-barang (goods) adalah objek yang diproduksi berdasarkan relasi kebutuhan pasar ditandai dengan nilai dalam sistem pertukaran. Aktan adalah terminologi akhir-akhir ini peristilahan dari sosiologi ilmiah yang merujuk pada entitas baik manusia maupun benda yang memiliki kemampuan untuk bertindak secara sosial. Objek kebudayaan material memiliki empat peranan penting dalam kehidupan manusia yaitu sebagai (1) penanda nilai, (2) penanda identitas, (3) serta wujud jaringan kekuasaan (4) sebagai wadah mitos. Objek kebudayaan material diberi nilai-nilai yang disepakati dan berlaku bagi 
masyarakatnya, objek kebudayaan material seni di dalamnya mengadung ide, gagasan serta nilai-nilai yang sesuai dengan konteks masyarakatnya.

Penelitian objek kebudayaan material seni menggunakan semiotika Roland Barthes melakukan tahapan-tahapan utama yaitu yang pertama melihat struktur seluruh tanda-tanda yang tampak dalam kajian benda material tersebut. Secara cermat memastikan segala aspek benda material utama sesuai fokus penelitian dapat tertangkap dan diungkapkan makna denotasinya sesuai dengan proses pemikiran sistem primer. Langkah kedua adalah mengkaji pesan-pesan budaya material tersebut malalui pesan-pesan teks, dokumen, karya sastra, literatur sesuai peristiwa dan konteksnya dan menemukan sistem pengetahuan/wacana masyarakatnya yang memunculkan mitos-mitos yang diterima oleh masyarakatnya. Langkah ketiga adalah pencarian makna sistem sekunder dengan menelusuri form dan concept-nya dan didapatkan sign baru, signification. Akhirnya menemukan makna sistem sekunder yang dapat berupa metabahasa, di mana perubahan yang terjadi adalah pada bagian ekspression dan makna sistem sekunder perubahan yang terjadi pada bagian isi atau content-nya.

\section{Daftar Pustaka}

Barker, Chris. 2008. Cultural Studies Theory and Practice. California: SAGE Publication Inc.

Barthes, Roland. (1981). Elemnts of Semiology. English Translation: Jonathan. New York: Hill and Wang.

(2007). Petualangan Semiologi. Terjemahan: Stephanus Aswar Herwinarko. Yogyakarta: Pustaka Pelajar

(2013). Mitologi Terjemahan: Nurhadi, A. Sihabul Milah. Yogyakarta: Kreasi Wacana

Foucault, Michel. (1973). The Archaeology of Knowledge. London: Tavistock Publications. 
(1976). Arkeologi Pengetahuan. Terjemahan Inyiak Ridwan Muzir. Yogyakarta: IRCiSoD.

Graham, Gordon. 1997. Philosophy of The Arts An Introduction to Aesthetic. New York: Routledge.

Hoed, Benny H. 2014. Semiotik dan Dinamika Sosial Budaya. Depok: Komunitas Bambu.

2011. Semiotik dan Dinamika Sosial Budaya. Depok : Komunitas Bambu.

Kali, Ampy. 2013. Diskursus Seksualitas Michel Foucault. Maumere: Ledalero.

Klimchuk, Marianne Rosner dan Sandra A. Krasovic. 2006. Desain Kemasan Perencanaan Merek Produk yang Berhasil Muai dari Konsep sampai Penjualan.Terjemahan: Bob Sabran. Jakarta: Penerbit Erlangga.

Pradoko, Susilo. 2015. Perubahan Pemaknaan Candi Siwa Prambanan Sejak Abad Ke-9 hingga Abad Ke-20: Kajian Arkeologi Pengetahuan. Disertasi S3 Universitas Indonesia, Depok.

2014. "Gemelan Sekaten Fenomena Penuh Makna dan Multi Perspektif:

Kajian Kebudayaan Materi”, Sembada, Jurnal Kebudayaan Kabupaten Sleman.

Poerbatjaraka, R.M.Ng. 2010. Ramayana Djawa Kuna Teks dan Terjemahan Sarga I-XII. Jakarta: Perpustakaan Nasional.

Rabinow, Paul. 2002. Aesthetic, Method, and Epistemplogy: Essential Works of Foucault 1954-1984. Terjemahan Arief (Pengetahuan dan Metode Karya-karya Penting Foucault). Yogyakarta: Jalasutra.

Rajagopalachari, C. 2012. Kitab Epos Ramayana. Terjemahan:Yudhi Murtanto. Yogyakarta: IRCiSoD.

Sony Kartika, Dharsono. 2007. Kritik Seni. Bandung: Penerbit Rekayasa Sain

Sunardi, ST. 2004. Semiotika Negativa. Yogyakarta: Penerbit Buku Baik.

Tolstoy, Leo. 1979." What is Art ?" dalam Art and Philosophy, W.E Kennick. Hal 34-45. New York: St Martin's Press.

Woodward, Ian. 2007. "The Material as Culture: Definitions, Perspectives, Approaches". Understanding Material Culture. Los Angeles: Sage Publication, Hal 3 - 16. 
